\title{
The Relationship between KIT Copy Number Variation, Protein Expression, and Angiogenesis in Sporadic Breast Cancer
}

\author{
Maryam Rahimi ${ }^{1,2}$, Farkhondeh Behjati ${ }^{1}$, Hamid Reza Khorram Khorshid ${ }^{1}$, \\ Masoud Karimlou ${ }^{3}$, Elahe Keyhani*1,4
}

\begin{abstract}
Background: KIT is a protooncogene that encodes for the KIT oncoprotein, which is a transmembrane tyrosine kinase growth factor receptor that holds a critical role in a variety of normal physiological and pathological processes including angiogenesis. KIT has been shown to be involved in tumorigenesis, contributing to the development of gastrointestinal carcinoma and leukemia. A link between KIT overexpression and breast cancer development has previously been reported. In the current study, we explored $K I T$ gene expression and exonic copy number variants (CNV) and the relationship with angiogenesis (CD34) and the clinicopathological features of breast cancer.

Methods: MLPA technique was used to determine the CNV in 64 breast cancer tumor samples from patients diagnosed with primary sporadic breast cancer. Results were confirmed by quantitative PCR. Expression of KIT and CD34 was determined using immunohistochemistry (IHC).

Results: Our results show that $28.1 \%$ of the tumor samples from patients with primary sporadic breast cancer had CNV in the KIT gene. Among the breast tumor samples, 54.7\% showed positive KIT expression. The expression of the CD34 angiogenesis marker was reported in $43.8 \%$ of the tumor samples as low, $42.2 \%$ as moderate and $14.1 \%$ as high. A significant correlation between increased CNV of KIT exons, a high level of angiogenesis (CD34) and increased tumor grade was observed $(\mathrm{p}<0.05)$.

Conclusions: A significant correlation between the KIT CNV and the angiogenesis marker was found. Examining KIT expression and CNV has the potential to function as a biomarker for tyrosine kinase inhibitor drugs in breast cancer.
\end{abstract}

Keywords: Angiogenesis, Breast Cancer, CD34, KIT.

\section{Introduction}

Breast cancer is the most commonly diagnosed malignancy in women worldwide, after nonmelanoma skin cancer and is one of the leading causes of mortality. Of the diagnosed cases of breast cancer, $80 \%-85 \%$ are considered sporadic with no prior family history or hereditary cause (1-3). Angiogenesis, the formation of new blood vessels, is understood to hold an essential role in breast cancer progression and dissemination by promoting both local tumor growth and metastasis. In its absence, tumor growth and metastasis are restricted significantly limiting tumor growth to roughly $2 \mathrm{~mm}(4,5)$. KIT (CD117) is a protooncogene that encodes for a type-III tyrosine kinase receptor involved in signal transduction in a variety of cell types. Normally, the KIT protein is activated upon binding to its ligand, the stem cell factor (SCF). This 
phosphorylation cascade leads to the activation of various transcription factors that regulate apoptosis, cell differentiation, proliferation and angiogenesis $(6,7)$.

CD34 is known as an angiogenesis marker, which can influence KIT gene expression (8). Of the final tyrosine kinase receptor, exons 1-9 of KIT gene encode for the extracellular domain, exon 10 encodes for a transmembrane domain, exon 11 encodes a juxtamembrane domain (JM), and exons 13-21 encode for the split tyrosine kinase domain (9).

Abnormalities in the KIT gene such as point mutations, deletions, and insertions and CNV leading to KIT overexpression have been shown to contribute to the development of various cancers including gastrointestinal carcinoma, leukemia, and melanoma (10-15). Previous research has demonstrated that the overexpression of the KIT gene holds a critical role in the development of different breast tumor subgroups such as phyllodes tumors and triple negative breast tumors. However, in most cases mutations were not found to cause KIT overexpression (1620). In malignant breast tumors, it has been shown that point mutations in KIT are rarely present (16). Additionally, a study reported that point mutations occur with low frequency in triple negative breast cancer (21). In a separate study, KIT gene CNVs of exon 15 and 18 was observed to be common in patients with phyllodes tumors and associated with KIT overexpression (22).

In inhibiting genes involved in angiogenesis, such as KIT gene, the development, progression, and migration of malignant tumors such as breast cancer can be suppressed. Therefore, this gene may serve as a potential target for cancer therapy $(23,24)$. The purpose of this study was to determine the relationship between KIT expression, $\mathrm{CNV}$ and CD34. Furthermore, we explored the connection between KIT gene expression and the clinicopathological features of sporadic breast cancer in Iranian women.

\section{Materials and methods Ethical approval}

All procedures performed in the study were in accordance with the ethical standards of the institutional research committee and with the
1964 Declaration of Helsinki and its later amendments or comparable ethical standards. This study has received approval from the ethics committee of "University of Social Welfare and Rehabilitation Sciences".

Informed consent was obtained from all individual participants included in the study.

\section{Patients and breast tissue samples}

We recruited 64 female patients diagnosed with primary sporadic breast cancer with no prior history of treatment, there were no restrictions on age or histopathological subtype. The referral hospital was the Mehrad Hospital in Tehran. Participants were provided with a written consent form explaining the procedures in the study. The consent forms were required to be signed prior to participation. Tumor samples were obtained from macroscopically visible tumor regions and confirmed by H\&E stained slides. DNA from the breast tumor samples was extracted, and the quality and integrity of the DNA was evaluated by agarose gel electrophoresis. The concentration of high-quality extracted DNA was standardized to a final volume of $125 \mathrm{ng}$ per reaction using a Nano Drop ND 2000 spectrophotometer.

\section{Multiplex Ligation-Dependent Probe Amplification (MLPA)}

We analyzed the presence of deletion and duplication mutations of KIT gene exons using the P354-A2 MLPA kit. The KIT gene contains 21 exons, spans $\sim 83 \mathrm{~kb}$ of genomic DNA and is located on $4 \mathrm{q} 12,55 \mathrm{Mb}$ from the p-telomere. The P354-A2 probemix contains two probes for exon 1 of the gene and one probe for each of the other exons. In addition, nine reference probes are included in this probemix, detecting several different autosomal chromosome locations. DNA extracted from the tumor and normal tissue samples, women without breast cancer, was preheated to $98{ }^{\circ} \mathrm{C}$, then salt solution and probe mix was added to the DNA. After the ligation of annealed nucleotides, PCR was performed to amplify target genes. PCR products were separated on an ABI3730-XL capillary sequencer (Applied Biosystems, Foster City, CA, USA). KIT gene copy number was determined using Coffalyser (ver. 
140721.1958). Cut-off values between 0.7 and 1.3 were considered normal. Results below 0.7 or above 1.3 were interpreted as deletion or duplication mutations of exons, respectively.

\section{Quantitative PCR}

Quantitative PCR (qPCR) was used to confirm the results of the MLPA. The qPCR mixes were prepared according to the Takara SYBR Master Mix instructions (Shiga, Japan) and were carried out using an ABI7500 PCR machine (Applied Biosystems, Foster City, CA). Data was analyzed by the $2^{-\Lambda C t}$ method, using SYBR green qPCR. The relative copy number of exons and genes was estimated by comparison with normal breast tissue control samples. We used RPPH1 housekeeping gene in normal breast tissue. Primer sequences for qPCR are shown in Table 1.

Table 1. Primer sequences for $\mathrm{q}-\mathrm{PCR}$ confirmations.

\begin{tabular}{ccl}
\multicolumn{2}{c}{ Table 1.Primer sequences for q-PCR confirmations. } \\
\multirow{2}{*}{ Exon 1 } & $\begin{array}{l}\text { Forward } \\
\text { Reverse }\end{array}$ & $\begin{array}{l}\text { GGATCCCATCGCAGCTACC } \\
\text { GAGTAGTCGCACGGTCGG }\end{array}$ \\
\hline \multirow{2}{*}{ Exon 2 } & $\begin{array}{l}\text { Forward } \\
\text { Reverse }\end{array}$ & GACTTTTGAGATCCTGGATGAAA \\
& GCCAAGCATTTACCTCTAACAA \\
\hline \multirow{2}{*}{ Exon 19 } & Forward & GCTTTGCAAACTGTGTCTCA \\
& Reverse & TGGCTCTTACATTTCAGCAGG \\
\hline \multirow{2}{*}{ Exon 21 } & Forward & GCTGTATTGACTATGGGCTTGT \\
& Reverse & TGACCCAAACACTGATTCTGC \\
\multirow{2}{*}{ RPPH1 } & Forward & GAGGTGAGTTCCCAGAGAACG \\
& Reverse & TTCGCTGGCCGTGAGTCTGTTC \\
\hline
\end{tabular}

\section{Immunohistochemistry}

The expression of KIT (CD117) at the tissue level was determined using Immunohistochemistry (IHC). Sections of paraffin blocks with $4 \mu \mathrm{m}$ thickness were used. IHC was performed using the CD117 antibody from DAKO (10103820, Glostrup, Denmark). IHC-Paraffin (ICH-P) refers to the staining of tissues that have been fixed (usually in neutral buffered formalin) and then embedded in paraffin before being sectioned. The basic steps of the IHC-P protocol are as follows: 4 $\mu$ m-thick mounted sections on slides from buffer (25) formaldehyde-fixed paraffin-embedded tissue blocks were deparaffinized and rehydrated in graded alcohols. The slides were then incubated with pre-diluted anti-CD117 antibody. Follow the incubation period, the sections were washed in PBS and incubated with horseradish peroxidase conjugated secondary antibody. Color development was performed using 3, 3'diaminobenzidine, and the tissue samples were counterstained with hematoxylin. Positive (positive gastrointestinal stromal tumor (GIST) slides) and negative external controls (normal skin tissue slides) were used to validate the test results. Samples were interpreted according to the ASCO/CAP guidelines: negative $(0,1+)$; weakly positive (2+); and strongly positive (3+) (Fig. 1). The slides were examined by a pathologist.

\section{Statistical analysis}

For data analysis, we used the SPSS 19.0 statistical package. Fisher's exact tests were used to analyze the association between CNV of KIT exons and gene expression, KIT expression and clinicopathological features, KIT expression and CD34 expression. A $p$-value of $<0.05$ was considered statistically significant.

\section{Results \\ Clinicopathology}

Clinicopathological data of the 64 patients included in this study is listed in Table 2.

\section{MLPA and $q P C R$}

MLPA analysis using SALSA P354-A2 kits was carried out successfully in all 64 breast tumor samples. Deletion and duplication mutations were present in 18 of the 64 tumor samples, examining all KIT gene exons (Table 3). In the remainder of the patient tumor samples, the $\mathrm{CNV}$ were not detected. Deletion and duplication mutations for 1, 2, 19, 21 exons were confirmed by qPCR.

\section{Immunohistochemistry}

Protein expression of the KIT receptor in the tumor tissue samples was determined using IHC staining. Our findings show $45.3 \%$ of breast 
tumor samples to have no KIT expression, $34.4 \%$ of tumor samples with low expression, $17.2 \%$ with moderate expression and $3.1 \%$ with high expression. IHC staining is shown in Figure 1 and the results are shown in Table 3. The scoring method for protein expression is as follows: score
1 , expression of at least $10 \%$ of cells with mild intensity; score 2, expression of at least $10 \%$ of cells with moderate intensity; score 3 , expression of at least $10 \%$ of cells with strong intensity. All of the normal breast tissue samples were found to be positive for the KIT protein.

Table 2. Clinicopathological data

\begin{tabular}{|c|c|c|}
\hline Characteristic & & $\mathrm{N}(\%)$ \\
\hline \multirow{3}{*}{ Stage } & I & $4(6.3)$ \\
\hline & II & $47(73.4)$ \\
\hline & III & $8(12.5)$ \\
\hline \multirow{3}{*}{ CD34 } & low & $28(43.8)$ \\
\hline & moderate & $27(42.2)$ \\
\hline & high & $9(14.1)$ \\
\hline \multirow{3}{*}{$\begin{array}{l}\text { Histologic } \\
\text { grade }\end{array}$} & I & $10(16.1)$ \\
\hline & II & $46(74.2)$ \\
\hline & III & $6(9.7)$ \\
\hline \multirow{2}{*}{ ER status } & Positive & 43 (67.2) \\
\hline & Negative & $19(29.7)$ \\
\hline \multirow{2}{*}{ PR status } & Positive & $38(59.4)$ \\
\hline & Negative & $24(37.5)$ \\
\hline \multirow{2}{*}{ HER2 status } & Positive & $29(45.3)$ \\
\hline & Negative & $33(51.6)$ \\
\hline \multirow{2}{*}{ Tumor size } & $<2 \mathrm{~cm}$ & $5(7.8)$ \\
\hline & $2-5 \mathrm{~cm}$ & $54(84.4)$ \\
\hline \multirow{2}{*}{ Age } & $<40$ years & $8(12.5)$ \\
\hline & $\geq 40$ years & $52(81.3)$ \\
\hline \multirow{2}{*}{$\begin{array}{l}\text { Histological } \\
\text { Type }\end{array}$} & aIDCA & $57(89.1)$ \\
\hline & bILCA & $4(6.3)$ \\
\hline \multirow{2}{*}{ Node status } & Positive & $29(45.3)$ \\
\hline & Negative & $30(46.9)$ \\
\hline \multirow{2}{*}{ Ki67 } & Positive & $10(15.6)$ \\
\hline & Negative & $52(81.3)$ \\
\hline \multirow{2}{*}{ Annexin V } & Positive & $10(20.8)$ \\
\hline & Negative & $38(79.2)$ \\
\hline \multirow{4}{*}{ Subtype } & luminal $\mathrm{A}$ & $36(56.3)$ \\
\hline & luminal B & $11(17.2)$ \\
\hline & Basal Like & $13(20.3)$ \\
\hline & ERBB2 & $2(3.1)$ \\
\hline
\end{tabular}

aIDCA = Invasive Ductal Carcinoma.

' ILCA= Invasive Lobular Carcinoma.

* Clinicopathological data of a number of patients not available. 


\section{KIT and Angiogenesis in Breast Cancer}

Table 3. The Mutation frequency in each of the KIT Exons

\begin{tabular}{|c|c|c|}
\hline \multicolumn{2}{|c|}{ CNV } & \multirow[b]{2}{*}{ Exons } \\
\hline $\begin{array}{c}\text { Yes } \\
\mathbf{N}(\%)\end{array}$ & $\begin{array}{c}\text { No } \\
\text { N }(\%)\end{array}$ & \\
\hline $15(23.4)$ & 49 (76.6) & 1 \\
\hline $7(10.9)$ & 57 (89.1) & 2 \\
\hline $4(6.2)$ & 60 (93.8) & 3 \\
\hline $4(6.2)$ & 60 (93.8) & 4 \\
\hline $6(9.4)$ & $58(90.6)$ & 5 \\
\hline $4(6.2)$ & $60(93.8)$ & 6 \\
\hline $4(6.2)$ & $60(93.8)$ & 7 \\
\hline $3(4.7)$ & $61(95.3)$ & 8 \\
\hline $6(9.4)$ & $58(90.6)$ & 9 \\
\hline $7(10.9)$ & $57(89.1)$ & 10 \\
\hline $7(10.9)$ & $57(89.1)$ & 11 \\
\hline $7(10.9)$ & $57(89.1)$ & 12 \\
\hline $5(7.8)$ & $59(92.2)$ & 13 \\
\hline $2(3.1)$ & $62(96.9)$ & 14 \\
\hline $5(7.8)$ & $59(92.2)$ & 15 \\
\hline $3(4.7)$ & 61 (95.3) & 16 \\
\hline $5(7.8)$ & $59(92.2)$ & 17 \\
\hline $6(9.4)$ & $58(90.6)$ & 18 \\
\hline $11(17.2)$ & $53(82.8)$ & 19 \\
\hline $7(10.9)$ & $57(89.1)$ & 20 \\
\hline $9(14.1)$ & $55(85.9)$ & 21 \\
\hline
\end{tabular}

A

B

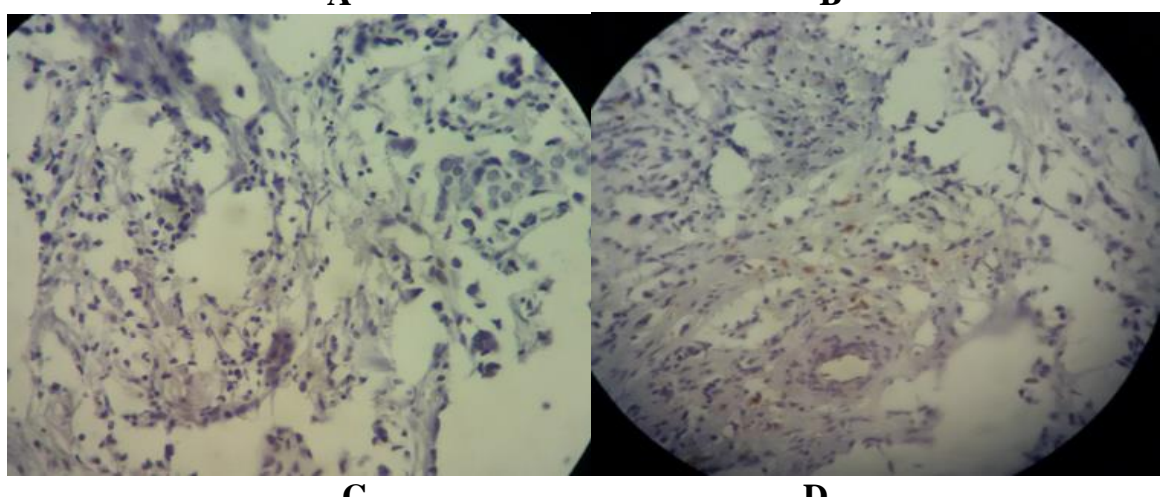

C

D

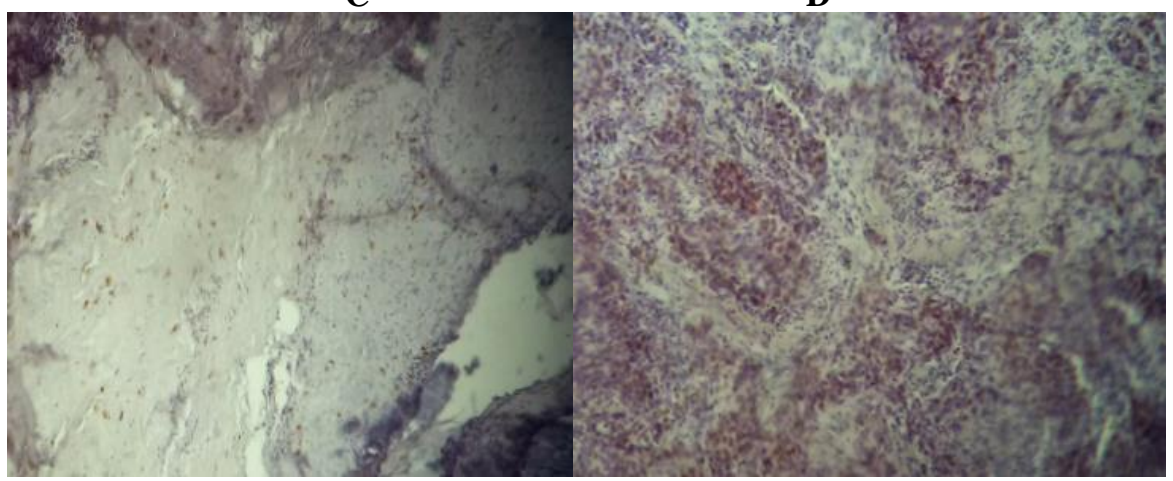

Fig. 1. KIT expression in the breast cancer.
A) Breast cancer tissue without KIT expression
B) Breast cancer tissue with low level of KIT expression.
C) Breast cancer tissue with moderate level of KIT expression.
D) Breast cancer tissue with high level of KIT expression. 


\section{Statistical analysis}

Table 4 shows the results of the comparisons between copies of KIT exons, its expression level, CD34 expression and histologic grade. Our results indicate a significant correlation between increased copy number in exon 1 , increase of CD34 expression and histological grade $(\mathrm{p}<$ 0.05). In addition, we found a significant correlation between increased copy number in exons 19 and 21 and histological grade $(\mathrm{p}<0.05)$.
The remaining exons did not show a significant relationship with the histological grade, CD34, or KIT expression ( $\mathrm{p}>0.05$ ). Correlation between KIT gene copy number, expression level and clinicopathological features are presented in Table 5. Our findings indicate that KIT gene CNVs are significantly correlated with increased CD34 expression and high histological grade $(\mathrm{p}<0.05)$.

Table 4: The relationship between the CNV in KIT gene exons, expression level, angiogenesis (CD34) and histologic grade. A value of p< 0.05 was considered statistically significant.

\begin{tabular}{|c|c|c|c|c|c|c|c|c|c|c|c|c|c|}
\hline \multirow[b]{2}{*}{ p value } & \multicolumn{3}{|c|}{$\begin{array}{c}\text { Histologic Grade } \\
\mathrm{N}(\%)\end{array}$} & \multicolumn{5}{|c|}{$\begin{array}{c}\text { CD34 expression } \\
\text { N(\%) }\end{array}$} & \multicolumn{4}{|c|}{$\begin{array}{c}\text { Expression level of } K I T \\
\text { N(\%) }\end{array}$} & \multirow{2}{*}{$\begin{array}{c}\text { Copy } \\
\text { Number } \\
\text { Variation } \\
\text { Exons } \\
\end{array}$} \\
\hline & 3 & 2 & 1 & $\begin{array}{c}P- \\
\text { value }\end{array}$ & $>40$ & $20-40$ & $<20$ & $P$-value & 3 & 2 & 1 & 0 & \\
\hline \multirow{2}{*}{0.02} & $\begin{array}{c}2 \\
(4.2)\end{array}$ & $\begin{array}{c}37 \\
(77.1)\end{array}$ & $\begin{array}{c}9 \\
(18.8)\end{array}$ & \multirow{2}{*}{0.04} & $\begin{array}{c}9 \\
(18.4)\end{array}$ & $\begin{array}{c}17 \\
(34.7)\end{array}$ & $\begin{array}{c}23 \\
(46.9)\end{array}$ & \multirow{2}{*}{0.95} & $\begin{array}{c}2 \\
(4.1)\end{array}$ & $\begin{array}{c}9 \\
(18.4)\end{array}$ & $\begin{array}{c}16 \\
(32.7)\end{array}$ & $\begin{array}{c}22 \\
(44.9)\end{array}$ & No \\
\hline & $\begin{array}{c}4 \\
(28.6)\end{array}$ & $\begin{array}{c}9 \\
(64.3)\end{array}$ & $\begin{array}{c}1 \\
(7.1)\end{array}$ & & $\begin{array}{c}0 \\
(0)\end{array}$ & $\begin{array}{c}10 \\
(66.7)\end{array}$ & $\begin{array}{c}5 \\
(33.3)\end{array}$ & & $\begin{array}{c}0 \\
(0)\end{array}$ & $\begin{array}{c}2 \\
(13.3)\end{array}$ & $\begin{array}{c}6 \\
(40)\end{array}$ & $\begin{array}{c}7 \\
(46.7)\end{array}$ & 1 \\
\hline \multirow{2}{*}{0.07} & $\begin{array}{c}3 \\
(5.8)\end{array}$ & $\begin{array}{c}40 \\
(76.9)\end{array}$ & $\begin{array}{c}9 \\
(173)\end{array}$ & \multirow{2}{*}{0.19} & $\begin{array}{c}9 \\
(17)\end{array}$ & $\begin{array}{c}20 \\
(37.7)\end{array}$ & $\begin{array}{c}24 \\
(45.3)\end{array}$ & \multirow{2}{*}{0.56} & $\begin{array}{c}2 \\
(3.8)\end{array}$ & $\begin{array}{c}10 \\
(18.9)\end{array}$ & $\begin{array}{c}16 \\
(30.2)\end{array}$ & $\begin{array}{c}25 \\
(47.2)\end{array}$ & \multirow{2}{*}{19} \\
\hline & $\begin{array}{c}3 \\
(30) \\
\end{array}$ & $\begin{array}{c}6 \\
(60) \\
\end{array}$ & $\begin{array}{c}1 \\
(10) \\
\end{array}$ & & $\begin{array}{l}0 \\
(0)\end{array}$ & $\begin{array}{c}7 \\
(63.6) \\
\end{array}$ & $\begin{array}{c}4 \\
(36.4)\end{array}$ & & $\begin{array}{c}0 \\
(0)\end{array}$ & $\begin{array}{c}1 \\
(9.9)\end{array}$ & $\begin{array}{c}6 \\
(54.5)\end{array}$ & $\begin{array}{c}4 \\
(36.4)\end{array}$ & \\
\hline \multirow{2}{*}{0.02} & $\begin{array}{c}3 \\
(5.7)\end{array}$ & $\begin{array}{c}40 \\
(75.5)\end{array}$ & $\begin{array}{c}10 \\
(18.9)\end{array}$ & \multirow{2}{*}{0.08} & $\begin{array}{c}9 \\
(16.4)\end{array}$ & $\begin{array}{c}20 \\
(36.4)\end{array}$ & $\begin{array}{c}26 \\
(47.3)\end{array}$ & \multirow{2}{*}{1.00} & $\begin{array}{c}2 \\
(3.6)\end{array}$ & $\begin{array}{c}10 \\
(18.2)\end{array}$ & $\begin{array}{c}19 \\
(34.5)\end{array}$ & $\begin{array}{c}24 \\
(43.6)\end{array}$ & No \\
\hline & $\begin{array}{c}3 \\
(33.3)\end{array}$ & $\begin{array}{c}6 \\
(66.7)\end{array}$ & $\begin{array}{c}0 \\
(0)\end{array}$ & & $\begin{array}{c}0 \\
0 \%\end{array}$ & $\begin{array}{c}7 \\
(77.8)\end{array}$ & $\begin{array}{c}2 \\
(22.2)\end{array}$ & & $\begin{array}{c}0 \\
(0)\end{array}$ & $\begin{array}{c}1 \\
(11.1)\end{array}$ & $\begin{array}{c}3 \\
(33.3)\end{array}$ & $\begin{array}{c}5 \\
(55.6)\end{array}$ & 21 \\
\hline
\end{tabular}

\section{Discussion}

KIT gene regulates cell differentiation, proliferation and angiogenesis pathways and is involved in the development of a variety of human malignancies, it has been a target of inhibitory drugs used for cancer treatment $(6,7)$. KIT expression has been observed to be increased in gastrointestinal cancers (90\%), leukemia (68\%), mast-cell tumors (70\%), and melanomas $(26,27)$. In these cancers, mutations such as point mutations, insertions, and deletions have been observed to be present in exons 9, 11, 13, and 17 of KIT. Of the mutations in KIT, an increase in copy number was the least reported (10-15). Conversely, in breast cancer increased copy number is more commonly reported than point mutations, insertions and deletions in exons (16-20). To date, no study has simultaneously investigated the $\mathrm{CNV}$ in all exons of the KIT gene. Thus, in this study all KIT gene exons were investigated simultaneously by using MLPA
(P354-A2 kit, MRC Holland). This kit was designed and routinely used for Peibaldism and contains probes for all exons. Therefore, it can be used to investigate $\mathrm{CNV}$ of exons and genes in patients with breast cancer. Our results show that $28.1 \%$ of the tumor samples from breast cancer patients had CNVs in the exons of KIT gene. Using this method, our study found exons 1, 2, 19, and 21 of the KIT gene to have the highest ratio of $\mathrm{CNV}$.

Within the KIT gene, exons 1 and 2 encode for the extracellular domain of the tyrosine kinase receptor that interacts with the SCF ligands involved in promoting angiogenesis. Therefore, increased copy number of these exons would lead to increased affinity of the SCF ligand to the tyrosine kinase receptor. Exons 19 and 21 encode for the tyrosine kinase domain involved in phosphorylation of the KIT receptor and therefore the activation of downstream factors. We studied 
KIT expression in 64 breast tumor samples isolated from women diagnosed with primary

Table 5. Clinicopathological variables in correlation to CNV of KIT gene and its expression level.

\section{CNV of KIT}

\begin{tabular}{|c|c|c|c|c|c|c|c|c|c|}
\hline \multicolumn{2}{|c|}{ Characteristic } & \multirow{2}{*}{$\begin{array}{l}\text { Yes } \\
\mathbf{N}(\%) \\
9(50)\end{array}$} & \multirow{2}{*}{$\begin{array}{l}\text { No } \\
\text { N(\%) } \\
20(43.5)\end{array}$} & \multirow[t]{2}{*}{${ }^{c} P$-value } & \multirow[t]{2}{*}{$\begin{array}{l}\mathbf{0} \\
\mathbf{N}(\%)\end{array}$} & \multirow[t]{2}{*}{$\begin{array}{l}1 \\
\mathrm{~N}(\%)\end{array}$} & \multirow[t]{2}{*}{$\begin{array}{l}2, \\
\mathbf{N}(\%)\end{array}$} & \multirow[t]{2}{*}{$\begin{array}{l}3 \\
\mathbf{N}(\%)\end{array}$} & \multirow[t]{2}{*}{$P$-value } \\
\hline & 0 & & & & & & & & \\
\hline Expression & 1 & $7(38.9)$ & $15(23.6)$ & \multirow{3}{*}{0.87} & & & & & \\
\hline level of $K I T$ & 2 & 2(11.1) & $9(19.6)$ & & & & & & \\
\hline & 3 & $0(0)$ & $2(4.3)$ & & & & & & \\
\hline \multirow{3}{*}{$\begin{array}{l}\text { CD34 } \\
\text { expression }\end{array}$} & $<20$ & $5(27.8)$ & $23(50)$ & \multirow{3}{*}{0.04} & $12(41.4)$ & $9(40.9)$ & $5(45.5)$ & $2(100)$ & \multirow{3}{*}{0.82} \\
\hline & $20-40$ & $12(66.7)$ & $15(32.6)$ & & $12(41.4)$ & $11(50)$ & $4(36.4)$ & $0(0)$ & \\
\hline & $>40$ & $1(5.6)$ & $8(17.4)$ & & $5(17.2)$ & $2(9.1)$ & $2(18.2)$ & $0(0)$ & \\
\hline \multirow{3}{*}{$\begin{array}{l}\text { Histologic } \\
\text { grade }\end{array}$} & I & $1(5.9)$ & $9(20)$ & \multirow{3}{*}{0.006} & $5(17.2)$ & $4(19)$ & $1(10)$ & $0(0)$ & \multirow{3}{*}{0.89} \\
\hline & II & $11(64.7)$ & $35(77.8)$ & & $21(72.4)$ & $14(66.7)$ & $9(90)$ & 2 & \\
\hline & III & $5(29.4)$ & $1(2.2)$ & & $3(10.3)$ & $3(14.3)$ & $0(0)$ & $0(0)$ & \\
\hline \multirow{2}{*}{ ER status } & Positive & $12(70.6)$ & 31 (68.9) & \multirow{2}{*}{1.00} & $18(62.1)$ & $16(76.2)$ & $7(70)$ & $2(100)$ & \multirow{2}{*}{0.62} \\
\hline & Negative & $5(29.4)$ & $14(31.1)$ & & $11(37.9)$ & $5(23.8)$ & $3(30)$ & $0(0)$ & \\
\hline \multirow{2}{*}{ PR status } & Positive & $8(47.1)$ & $30(66.7)$ & \multirow{2}{*}{0.24} & $15(51.7)$ & $14(66.7)$ & $7(70)$ & $2(100)$ & \multirow{2}{*}{0.51} \\
\hline & Negative & $9(52.9)$ & $15(33.3)$ & & $14(48.3)$ & $7(33.3)$ & $3(30)$ & $0(0)$ & \\
\hline \multirow{2}{*}{$\begin{array}{l}\text { HER2 } \\
\text { status }\end{array}$} & Positive & $8(47)$ & $21(46.7)$ & \multirow{2}{*}{0.87} & $11(41.4)$ & $11(57.1)$ & $3(30)$ & $2(100)$ & \multirow{2}{*}{0.32} \\
\hline & Negative & $9(53)$ & $24(53.4)$ & & $17(58.6)$ & $9(42.1)$ & $7(70)$ & $0(0)$ & \\
\hline \multirow{2}{*}{ Tumor size } & $<2 \mathrm{~cm}$ & $3(18.8)$ & $2(4.7)$ & 011 & $1(3.7)$ & $4(20)$ & $0(0)$ & $0(0)$ & חרד \\
\hline & $2-5 \mathrm{~cm}$ & $13(81.3)$ & $41(95.3)$ & 0.11 & $26(96.3)$ & $16(80)$ & $10(100)$ & $2(100)$ & 0.20 \\
\hline Ase & $<40$ years & $3(17.6)$ & $5(11.6)$ & 067 & $4(14.8)$ & $2(9.5)$ & $2(20)$ & $0(0)$ & 070 \\
\hline Age & $\geq 40$ years & $14(82.4)$ & $38(88.4)$ & 0.01 & $23(85.2)$ & $19(90.5)$ & $8(80)$ & $2(100)$ & 0.10 \\
\hline Histological & aDCA & $17(100)$ & $40(90.9)$ & 067 & $26(92.9)$ & $20(95.2)$ & $9(90)$ & $2(100)$ & 089 \\
\hline Type & bILCA & $0(0)$ & $4(9.1)$ & $0.0 /$ & $2(7.2)$ & $1(4.8)$ & $1(10)$ & $0(0)$ & 0.89 \\
\hline Node status & Positive & $8(50)$ & $21(48.8)$ & 100 & $13(48.1)$ & $10(50)$ & $7(70)$ & $0(0)$ & 034 \\
\hline & Negative & $8(50)$ & $22(51.2)$ & & $14(51.9)$ & $10(50)$ & $3(30)$ & $2(100)$ & \\
\hline Ki67 & Positive & $15(88.2)$ & 37 (82.2) & 071 & $23(79.3)$ & $19(90.5)$ & $8(80)$ & $2(100)$ & 060 \\
\hline K10/ & Negative & $2(11.8)$ & $8(17.8)$ & $0 . / 1$ & $6(20.7)$ & $2(9.5)$ & $2(20)$ & $0(0)$ & 0.09 \\
\hline & luminal A & $8(47.1)$ & $28(62.2)$ & & $13(44.8)$ & $15(71.4)$ & $6(60)$ & $2(100)$ & \\
\hline Subtyne & luminal B & $3(17.6)$ & $8(17.8)$ & 065 & $7(24.1)$ & $2(9.5)$ & $2(20)$ & $0(0)$ & 074 \\
\hline suotype & Basal Like & $5(29.4)$ & $8(17.8)$ & & $7(24.1)$ & 4(19) & $2(20)$ & $0(0)$ & 0.14 \\
\hline & ERBB2 & $1(5.9)$ & $1(2.2)$ & & $2(6.9)$ & $0(0)$ & $0(0)$ & $0(0)$ & \\
\hline "Annexin & Positive & $5(29.4)$ & $9(20)$ & 050 & $20(69)$ & $18(85.7)$ & $8(80)$ & $2(100)$ & 055 \\
\hline$V^{\prime \prime}$ & Negative & $12(70.6)$ & $36(80)$ & 0.00 & $9(31)$ & $3(14.3)$ & $2(20)$ & $0(0)$ & U.J. \\
\hline & I & $1(6.3)$ & $3(7.0)$ & & $1(3.7)$ & $3(15)$ & $0(0)$ & $0(0)$ & \\
\hline Stage & II & $11(68.8)$ & $36(83.7)$ & 0.23 & $23(85.2)$ & $13(65)$ & $10(100)$ & $1(50)$ & 0.19 \\
\hline & III & $4(6.8)$ & $49(25)$ & & $3(11.1)$ & $4(20)$ & $0(0)$ & $1(50)$ & \\
\hline
\end{tabular}

aIDCA = Invasive Ductal Carcinoma.

' $\mathrm{ILCA}=$ Invasive Lobular Carcinoma.

${ }^{c} P$-value from Fisher's Exact Test.

*clinicopathological data of a number of patients not available. 
sporadic breast cancer. Of the samples, $54.7 \%$ were positive for KIT and the remainder were negative. Previous studies have shown that KIT expression in non-cancerous breast tissue is different from that of malignant tumors and highgrade breast cancer (18-20).

Our findings did not show a significant relationship between increased copy number and overexpression of KIT. However, previous research has reported an increase in gene copy number as the reason for KIT overexpression. In contrast with other cancers, few results have shown point mutations, insertions and deletions in breast cancer $(21,28-30)$. Indeed, with the exceptions of the GISTs, no relationship between KIT activating mutations and KIT expression has been found in multiple types of tumors (31).

Similar to our findings, one study did not observe any significant correlation between increased KIT expression and gene copy number (20). This observation could be explained by translational, post-transcriptional and protein degradation regulation, indicating that some genes may be transcribed, however they are not displayed on the cell surface (32). Alternatively, this finding could be a result of epigenetic variation causing gene overexpression without alterations in the KIT gene. Therefore, it is other mechanisms may cause the increased KIT expression. It should be noted that the small sample size could also contribute to this discrepancy.

In the current study, we analyzed the relationship between $\mathrm{CNV}$ of all 21 exons in the KIT gene and protein expression. Our findings showed no significant correlation. Variations of exons that change the structure and function of proteins are important for administering tyrosine kinase inhibitor drugs, such as those for gastrointestinal tumors, as they are resistant to these drugs (12).

In a study by Chen et al, no correlation between CD34 expression, grade, tumor size and CD117 (KIT) expression was observed (33). The expression of KIT, CD34, and actin was investigated in 19 patients with breast phyllodes tumors. Compared with the benign tumors, malignant phyllodes tumor stromal lesions displayed an increased expression of KIT. Other genes may influence CD34 overexpression.

Furthermore, we examined the relationship between the KIT gene copy number, KIT expression and clinicopathological features of breast tumors. No significant correlation was found $(p>0.05)$. The small sample size may account for this lack of significance.

The current study demonstrated a significant correlation between an increase in CNV in KIT gene and a high level of CD34 expression as well as the high tumor grades $(p<0.05)$. Although there was no significant correlation between increased KIT expression and CD34 expression, KIT overexpression alone has the potential to be used as a biomarker for determining the effectiveness of tyrosine kinase inhibitor drugs in breast cancer therapy.

Many tyrosine kinase inhibitors exist which have been successfully administrated in various cancers such as gastrointestinal cancer and leukemia $(34,35)$. However, further studies with larger sample sizes are necessary to verify our findings and the effectiveness of tyrosine kinase inhibitors for breast cancer treatment.

A significant correlation between $\mathrm{CNV}$ in KIT gene exons and the CD34 angiogenesis marker within the breast tumor samples of patients with primary sporadic breast cancer. Thus, administration of the KIT inhibitor drugs may act to suppress breast cancer development and progression in patients with KIT overexpression and exonic CNV.

\section{Acknowledgment}

This study was supported by the Genetics Research Center, University of Social Welfare and Rehabilitation Sciences, Tehran, Iran. (94/801/A/6/8114). All authors declare that they have no conflict of interests. 


\section{References}

1. Druillennec S, Dorard C, Eychene A. Alternative Splicing in Oncogenic Kinases: From Physiological Functions to Cancer. J Nucleic Acids. 2012;2012:639062.

2. Mousavi SM, Montazeri A, Mohagheghi MA, Jarrahi AM, Harirchi I, Najafi M, et al. Breast cancer in Iran: an epidemiological review. Breast J. 2007;13:383-91.

3. Keyhani E, Muhammadnejad A, Behjati F, Sirati F, Khodadadi F, Karimlou M, et al. Angiogenesis Markers in Breast Cancer Potentially Useful Tools for Priority Setting of Anti-Angiogenic Agents. Asian Pac J Cancer Prev. 2013;14:7651-6.

4. Shimizu K, Oku N. Cancer anti-antiogenic therapy. Biol Pharm Bull. 2004; 27:599-605.

5. De Jong JS, van Diest PJ, Baak JP. Hot spot microvessel density and mitotic activity index are strong additional prognostic indicators in invasive breast cancer. Histopathology. 2000;36:306-312.

6. Kondi-Pafiti A, Arkadopoulos N, Gennatas C, Michalaki V, Frangou-Plegmenou M, Chatzipantelis P. Expression of c-kit in common benign and malignant breast lesions. Tumori. 2010;96:978-84.

7. McIntyre A, Summersgill B, Grygalewicz B, Gillis AJ, Stoop J, van Gurp RJ, et al. Amplification and overexpression of the KIT gene is associated with progression in the seminoma subtype of testicular germ cell tumors of adolescents and adults. Cancer Res. 2005;65(18): 8085-9.

8. Crosby H A, Kelly D A, Strain J A. Human hepatic stem-like cells isolated using c-kit or CD34 can differentiate into biliary epithelium. Gastroenterology. 2001;120(2):534-44.

9. Miettinen M, Lasota J. KIT (CD117): A Review on Expression in Normal and Neoplastic Tissues, and Mutations and Their Clinicopathologic Correlation. Appl Immunohistochem Mol Morphol. 2005;13(3):205-20.

10. Tuveson D, Willis N, Jacks T, Gri J, Singer S. STI571 inactivation of the gastrointestinal stromal tumor c-KIT oncoprotein: biological and clinical implications. Oncogene. 2001;20(36):5054-8.

11. Orsenigo M, Brich S, Riva C, Conca E, Bertulli $\mathrm{R}$, Dileo $\mathrm{P}$, et al. Fluorescence in situ hybridization analysis and immunophenotyping of c$\mathrm{Kit} / \mathrm{PDGFRA}$ and Bcl-2 expression in gastrointestinal stromal tumors. Anal Quant Cytol Histol. 2010;32(4):225-33.

12. Antonescu C, Romeo S, Zhang L, Nafa K, Hornick J, Nielsen G, et al. Dedifferentiation in Gastrointestinal Stromal Tumor to an Anaplastic KIT Negative Phenotype: A Diagnostic Pitfall. Morphologic and Molecular Characterization of 8 Cases Occurring either de-novo or after Imatinib Therapy.Am J Surg Pathol. 2013;37(3):385-92.

13. Malaise M, D, Corbacioglu S. Clinical implications of c-Kit mutations in acute myelogenous leukemia. Curr Hematol Malig Rep. 2009;4(2):77-82.

14. Renneville A, Roumier C, Biggio V, Nibourel $\mathrm{O}$, Boissel N, Fenaux P, et al. Cooperating gene mutations in acute myeloid leukemia: a review of the literature. Leukemia. 2008;22(5):915-31.

15. Beadling C, Jacobson-Dunlop E, Hodi FS, Le C, Warrick A, Patterson J, et al. KIT gene mutations and copy number in melanoma subtypes. Clin Cancer Res. 2008;14(21):6821-8.

16. Lee JY, Park K, Lim S H, Kim H S, Yoo K H, Jung $\mathrm{K} \mathrm{S}$, et al. Mutational profiling of brain metastasis from breast cancer: matched pair analysis of targeted sequencing between brain metastasis and primary breast cancer. Oncotarget. 2015;6(41):43731-42.

17. Gilbert JA, Goetz MP, Reynolds CA, Ingle JN, Giordano KF. Molecular analysis of metaplastic breast carcinoma. Mol Cancer Ther. 2008;7(4):944-51.

18. Kondi-Pafiti A, Arkadopoulos N, Gennatas C, Michalaki V, Frangou-Plegmenou M, Chatzipantelis P. Expression of c-kit in common benign and malignant breast lesions. Tumori. 2010;96(6):978-84

19. Johansson I, Aaltonen EK, Ebbesson A, Grabau D, Wigerup C, Hedenfalk I. Increased Gene Copy Number of KIT and VEGFR2 at 4q12 in Primary Breast Cancer is Related to an Aggressive Phenotype and Impaired Prognosis. Genes Chromosomes Cancer. 2012;51(4):375-83 20. Jansson S, Bendah P, Grabau D, Falck A, Aaltonen K. The Three Receptor Tyrosine Kinases c-KIT, VEGFR2 and PDGFRa, Closely Spaced at 
4q12, Show Increased Protein Expression in Triple-Negative Breast Cancer. PLoS One. 2014;9(7):e102176.

21. Zhu Y, Wang Y, Guan B, Rao Q, Wang J, Ma $\mathrm{H}$, et al. C-kit and PDGFRA gene mutations in triple negative breast cancer. Int J Clin Exp Pathol. 2014;7(7):4280-5.

22. Liu J, Liu X, Feng X, Liu J, Lv S, Zhang W, et al. C-kit overexpression correlates with KIT gene copy numbers increases in phyllodes tumors of the breast. Breast Cancer Res Treat. 2015;149(2):395-401.

23. Ribatti D, Nico B, Crivellato E, Roccaro AM, Vacca A. The history of angiogenic switch concept. Leukemia. 2007;21(1):44-52.

24. Rahimi M, Behjati F, Taheri N, Hosseini S, Khorram Khorshid HR, Aghakhani Moghaddam $\mathrm{F}$, et al. Correlation between Important Genes of mTOR Pathway (PI3K and KIT) in Iranian Women with Sporadic Breast Cancer. Med J Islam Repub Iran. 2018;32:135.

25. Canene-Adams K. Preparation of formalinfixed paraffin-embedded tissue for immunohistochemistry. Methods Enzymol. 2013;533:225-33.

26. Heinrich MC, Blanke CD, Druker BJ, Corless CL. Inhibition of KIT tyrosine kinase activity: a novel molecular approach to the treatment of KIT-positive malignancies. J ClinOncol. 2002;20:1692-703.

27. Dybko J, Haus O, Jazwiec B, Urbaniak J, Wozniak M, Kaczmar-Dybko A, et al. CD117 (ckit) expression on CD34? Cells participates in the cytogenetic response to imatinib in patients with chronic myeloid leukemia in the first chronic phase. Acta Haematol. 2014;132:166-71.
28. Carvalho S, Silva A, Milanezi F, Ricardo S, Leita $\mathrm{D}$, Amendoeira I, et al. c-KIT and PDGFRA in breast phyllodes tumours: Over expression without mutations?. J Clin Pathol. 2004;57(10):1075-1079.

29. Simon R, Panussis S, Maurer R, Spichtin H, Glatz K, Tapia C, et al. KIT (CD117)-Positive Breast Cancers Are Infrequent and Lack KIT gene Mutations. Clin Cancer Res. 2004;10(1 Pt 1):178-83.

30. Bose P, Dunn ST, Yang J, Allen R, EL-Khoury C, Tfayli A. c-Kit Expression and Mutations in Phyllodes Tumors of the Breast. Anticancer Res. 2010;30(11):4731-6.

31. Miettinen M, Lasota J. KIT (CD117): a review on expression in normal and neoplastic tissues, and mutations and their clinicopathologic correlation. Appl Immunohistochem Mol Morphol. 2005;13(3):205-20.

32. Arvas M, Pakula T, Smit B, Rautio J, Koivistoinen H. Correlation of gene expression and protein production rate - a system wide study. BMC Genomics. 2011;12(1):616.

33. Chen CM, Chen CJ, Chang CL, Shyu JS, Hsieh HF, Harn HJ. CD34, CD117, and actin expression in phyllodes tumor of the breast. J Surg Res. 2000;94(2):84-91.

34. Poveda A, del Muro XG, Lopez-Guerrero JA, Martinez V, Romero I, Valverde C, et al. GEIS 2013 guidelines for gastrointestinal sarcomas (GIST). Cancer Chemother Pharmacol. 2014;74(5):883-98.

35. Heinrich MC, Blanke CD, Druker BJ, Corless CL. Inhibition of KIT tyrosine kinase activity: a novel molecular approach to the treatment of KITpositive malignancies. $\mathrm{J}$ Clin Oncol. 2002;20(6):1692-703. 